\title{
ЯЗЫКОВОЕ ПОВЕДЕНИЕ И КОМПЕТЕНЦИИ АДЫГЕЙСКОГО СТУДЕНЧЕСТВА*
}

\begin{abstract}
Вопрос языковых компетенций адыгейского студенчества, знание адыгейского языка и его бытование продолжительное время находятся в поле зрения адыгейской общественности. в СМИ и сетях интернет периодически обсуждается тема «утраты адыгейского языка» молодежью и его «скорая гибель». Автор статьи, на основе результатов массового опроса, проведенного в городе Майкоп, рассматривает языковые компетенции и сферы применения языков студенческой молодежью Республики Адыгея. Они показывают, что большая часть респондентов чаще используют русский язык в общении на улице, учебе и работе. Адыгейский язык превалирует исключительно в домашнем общении. При этом, показано, что городская молодежь в отличие от сельской реже использует адыгейский язык, отдавая предпочтение русскому. Практически все респонденты знают русский на высоком уровне, т.е. думают на нем, читают и пимут, в то время, как для адыгейского языка доля студентов адыгов, указавиих подобный уровень, составляет менее 2/3. Применяя дополнительную литературу, а также материалы интервью, автор объясняет проиессы вытеснения адыгейского языка в бытовую, домашнюю среду, а также причины большой разницы в знании и использовании языка между респондентами, родившимися в городе или селе. Так, среди отмеченных причин находятся изменения в экономике, активная урбанизация и внутренние миграции, формирование более полиэтничной среды в аулах, проблемы в икольном и высшем образовании.
\end{abstract}

Ключевые слова: языковое поведение, адыгейский язык, адыги, Адыгея, языка Ссылка при цитировании: Донежук М.С. Языковое поведение и компетенции адыгейского студенчества // Вестник антропологии, 2021. № 4. С. 75-91.

\section{Введение}

На протяжении продолжительного времени в СМИ и интернет среде публикуются записи по типу: «Черкесский язык находится на грани полного исчезновения в ближайшие десятилетия. Основным фактором уязвимости черкесского языка является его ограниченное употребление в публичных сферах» (Черкесскому языку), «Все адыгские дети должны знать родной язык, и никак нельзя считать нормальным, что сотни школьников не умеют читать и писать на родном языке...Присмотритесь,

Донежук Мурат Юсуфович - аспирант, стажер-исследователь, Институт этнологии и антропологии РАН (119991 Москва, Ленинский просп., 32а). Эл. почта: donmur@iea.ras.ru *Статья подготовлена при финансовой поддержке РФФИ грант «19-09-00482 А» 
как мы, адыги, разговариваем между собой: наполовину по-адыгски, наполовину на русском, а чаще всего и вовсе на русском языке» (Мы должны). Часто встречается утверждение, что городские дети хуже знают адыгейский язык и реже на нем общаются. в 2009 году ЮНЕСКО включила адыгейский язык в список уязвимых языков, что также стало поводом для появления множества публикаций, в которых ситуацию с адыгейским языком назвали критической. Вопросом сохранения языка заинтересовалась общественная организация «Адыгэ Хасэ - Черкесский парламент», производящая мониторинг оснащенности школ Республики Адыгея учебниками на адыгейском языке. Факультет адыгейской филологии и культуры выпустил воззвание к родителям Республики Адыгея, где говорится, что «Сегодня, адыгейский язык ускользает из наших рук...Над нами нависла угроза исчезновения языка». Сильный толчок этой теме дала инициатива Государственной думы о принятии поправок в закон «Об образовании в Российской Федерации», основным положением которой является добровольное изучение национальных языков народов Российской Федерации, которая подверглась критике в адыгском сообществе.

В связи с этим, в этой статье мы рассмотрим два основных вопроса: каков уровень владения адыгейским и русским языком у адыгейской студенческой молодежи, а также сушествует ли зависимость уровня владения языками от места рождения респондентов.

Изучением языкового поведения и языковых компетенций занималось большое количество специалистов. Так, О.М. Цветков и 3.Х. Гучетль, изучая проблемы, связанные с употреблением адыгейского языка в разных сферах жизни, пишут следующее: «Адыгейский язык функционирует и воспроизводится, в основном, в местах компактного проживания адыгов, в моноэтнических семьях, в других локальных моноэтнических группах. Его функционирование поддерживается также учебными заведениями, телевидением и радио на адыгейском языке, выпуском литературы и газетой на адыгейском языке», но тут же отмечают, что количество выделенных часов для изучения адыгейского языка недостаточно, а функционирующие на адыгейском языке СМИ не имеют необходимого охвата: «Среду, в которой происходит его функционирование, нельзя назвать благоприятной. в долгосрочной перспективе языку угрожает исчезновение» (Цветков 2018: 489). Похожие процессы в причерноморской Шапсугии описывает И.Л. Бабич. в ее работе «Современные языковые процессы как фактор национальной идентичности причерноморских адыгов-шапсугов» рассматривается тенденция к постепенному увеличению доли русского языка в разных сферах жизни шапсугов, в том числе и в домашнем общении. Помимо этого, предлагается несколько причин, с которыми, по всей видимости, связана «сдача позиций» шапсугским и литературным адыгейским языками. Среди них - вытеснение шапсугского языка из экономической, т.е. трудовой сферы в сферу домашнего общения, что является во многом универсальным сценарием как для причерноморской Шапсугии, так и для Республики Адыгея (Бабич 2020: 157-158). Как отмечает В.Н. Нехай, в Адыгее имеются некоторые организации, выступающие за упразднение государственного статуса адыгейского языка, что в свою очередь может отрицательно сказаться на языковой ситуации в Адыгее (Нехай 2008: 103-104). Авторы статьи «Лексикографическая база данных адыгских языков: основные принципы построения» также указывают на смещение адыгейского языка в сферу домашнего общения: «...Из повседневной лексики выпали целые пласты лексики, в том 
числе термины, устойчивые выражения, связанные с различными областями жизнедеятельности человека. За последние десятилетия этот процесс ускоряется. Сфера применения языка существенно сузилась и свелась преимущественно к уровню семейно-бытового общения» (Унарокова 2017: 128-129). Денисова А.В., проводя сравнение между республиками Крым, Калмыкия и Адыгея в отношении языковых предпочтений молодежи указанных субъектов, по результатам опросов пришла к выводу, «что во всех республиках при абсолютном доминировании русского языка во всех сферах жизни, значительная часть молодежи использует также национальные языки. в частности, в Крыму национальные языки использует не менее трети молодежи, в Адыгее - 49,7\%, в Калмыкии - 47,2 \%» (Денисова 2018: 156).

Данная работа основывается на результатах опроса адыгейской молодежи, обучающейся в университетах и колледжах города Майкоп: Адыгейском государственном университете, Майкопском государственном технологическом университете, Майкопском государственном гуманитарно-техническом колледже и в Адыгейском педагогическом колледже им. Х. Андрухаева. Опрос производился посредством анкетирования в 4 вариантах: анкетирование при личном участии интервьюера $-67 \%$ респондентов, использование Google-формы - 15\%, раздача анкет преподавателями $14 \%$, а также $4 \%$ было опрошено при поддержке добровольцев. в общей сложности, опрошено 320 адыгов, из которых 44\% являются мужчинами, а 56\% женщинами. Исходя из данных РОССТАТА, можно сказать, что полученная нами половозрастная выборка соответствует действительности, т.е. женщин среди обучающихся в вузах больше (Женщины и мужчины 2020: 76). Соотношение университет/колледж составляет $52 \%$ и $33 \%$ респондентов соответственно. Поскольку 15\% человек опрошены посредством Google-форм, неизвестно в каких вузах они обучаются. Родились в Республике Адыгея 284 респондента, небольшая их часть (29 человек) родом из других субъектов и еще 7 - иностранные граждане. Половина респондентов - урожденные горожане (50\%), а $42 \%$ родились в сельской местности. Оказалось, что $7 \%$ опрошенных указали только название региона, $1 \%$ вовсе не ответили на этот вопрос.

Заметим, что результаты опроса позволяют судить о саморепрезентации респондентов, но не о фактическом уровне владения языком, т.к. для этого требуется социолингвистическое исследование, подразумевающее проверку тех или иных навыков владения языком. в связи с этим, стоит еще раз оговориться, что выводы, которые можно будет сделать исходя из полученных данных, будут касаться исключительно оценочного мнения респондентов.

Рассмотрение вопросов будет производиться по трем направлениям: соотношение результатов исследования между мужчинами и женщинами; между студентами университетов и колледжей; между респондентами, родившимися в городе и сельской местности.

\section{Какими языками владеют респонденты}

Как показывают результаты проведенного опроса, абсолютное большинство респондентов владеют русским языком. Доля таковых составляет 97\%, а с учетом того, что опрос производился на русском языке, этот показатель можно считать, как $100 \%$. Адыгейским же языком владеет меньшее количество респондентов - 85\%. Также учитывались те, кто указал кабардинский и черкесский языки. Последние были объ- 
единены в общую группу «Кабардино-черкесский», насчитывающую нескольким более $1 \%$. Подробные цифры приведены в таблице № 1 .

Таблица 1

Какими языками владеют респонденты (в \%)

\begin{tabular}{|c|c|c|c|c|c|}
\hline \multirow{2}{*}{ Вариант } & \multirow{2}{*}{ Общие } & \multicolumn{2}{|c|}{ Пол } & \multicolumn{2}{|c|}{ Место рождения } \\
\hline & & Мужчины & Женшины & Город & Село \\
\hline Адыгейский & 85,3 & 82,3 & 87,7 & 74,4 & 96,3 \\
\hline Кабардино-черкесский & 1,3 & 0,7 & 1,7 & 1,3 & 1,5 \\
\hline Русский & 96,9 & 97,2 & 96,6 & 96,3 & 97 \\
\hline
\end{tabular}

Из приведенных данных очевидно, что мужчины и женщины в сопоставимом соотношении владеют указанными языками. Доли «горожан» и «селян», владеющих русским и кабардино-черкесским языками в целом равны. Тем не менее, заметно, что даже первый вопрос, связанный с адыгейским языком, показывает определенную связь с местом рождения и знания адыгейского языка. Так, 96\% уроженцев сельской местности владеют адыгейским языком, в то время, как среди «горожан» этот показатель ниже более чем на 20\%.

\section{Оценка респондентами своего знания языков}

Второй вопрос, посвященный языку, подразумевал возможность оценки самим респондентом, на каком уровне он владеет адыгейским и русским языком. Было предложено четыре варианта ответа по убыванию: 1. Думаю на этом языке, свободно говорю, читаю и пишу; 2. Могу говорить и читать, но думаю на другом языке; 3. Говорю с затруднениями; 4. Не знаю язык.

По оценкам респондентов, в целом они очень хорошо знают русский язык и, как говорилось выше, владеют им все опрошенные, т.к. сам опрос проходил на русском языке, и никто не выбрал вариант «Не знаю язык». Более $90 \%$ студентов знают русский язык на самом высоком из предложенных уровней, т.е. думают на нем. Около $6 \%$ знают его хорошо, но думают на другом. в целом, заметно, что эти показатели не зависят от пола и места рождения. Хотя, среди женщин и горожан доля тех, кто говорит на русском языке с затруднениями выше, нежели в других группах. Это объясняется тем, что это респонденты адыги - граждане других стран, относительно недавно проживающие в Адыгее.

На адыгейском языке думает более $60 \%$ опрошенных, что на $30 \%$ меньше думающих на русском языке. Читают и говорят, но думают на другом языке $16 \%$ и чуть больше тех, кто говорит на адыгейском языке с затруднениями - 17\%. Не знающих язык $-4 \%$. Между мужчинами и женщинами нет большой разницы в ответах, отклонения находятся в диапазоне одного процента. Касаемо соотношения город/село, заметно очередное проседание первой группы. Так, если $82 \%$ уроженцев сел думают 
на адыгейском языке, то этот же показатель для города составляет 46\%, что почти вдвое меньше чем у сельчан. Похожая ситуация с теми, кто говорит и читает на адыгейском, а думает на отличном от него языке. Среди сельской молодежи таковых меньше, т.е. доля тех, кто знает язык хуже, среди сельчан меньше и составляет 10\% против более чем 20\% у горожан. Четверть городской молодежи (25\%) говорит на этом языке с затруднениями. Для сельчан, доля таковых составляет только десятую часть респондентов. Среди тех, кто выбрал вариант «Не знаю язык», перевес у уроженцев города, причем, в этом случае он больше почти в пять раз: 7,4\% у городской молодежи против $1,5 \%$ у сельской.

Таблица 2

На каком уровне респонденты знают русский язык (в \%)

\begin{tabular}{|c|c|c|c|c|c|}
\hline \multirow{2}{*}{ Вариант } & \multirow{2}{*}{ Общие } & \multicolumn{2}{|c|}{ Пол } & \multicolumn{2}{|c|}{ Место рождения } \\
\hline & & Мужчины & Женщины & Город & Село \\
\hline $\begin{array}{l}\text { Думаю на этом языке, свободно } \\
\text { говорю, читаю и пишу }\end{array}$ & 92,8 & 92,9 & 92,7 & 92,5 & 93,3 \\
\hline $\begin{array}{l}\text { Могу говорить и читать, } \\
\text { но думаю на другом языке }\end{array}$ & 5,6 & 7,1 & 4,5 & 5,6 & 5,2 \\
\hline Говорю с затруднениями & 0,6 & 0 & 1,1 & 1,3 & 0 \\
\hline Не знаю язык & 0 & 0 & 0 & 0 & 0 \\
\hline
\end{tabular}

Таблица 3

На каком уровне респонденты знают адыгейский язык (в \%)

\begin{tabular}{|c|c|c|c|c|c|}
\hline \multirow{2}{*}{ Вариант } & \multirow{2}{*}{ Общие } & \multicolumn{2}{|c|}{ Пол } & \multicolumn{2}{|c|}{ Место рождения } \\
\hline & & Мужчины & Женщины & Город & Село \\
\hline $\begin{array}{l}\text { Думаю на этом языке, свободно } \\
\text { говорю, читаю и пишу }\end{array}$ & 62,8 & 63,7 & 62,1 & 46,3 & 82,1 \\
\hline $\begin{array}{l}\text { Могу говорить и читать, но думаю } \\
\text { на другом языке }\end{array}$ & 16,2 & 15,6 & 16,7 & 21,5 & 9,7 \\
\hline Говорю с затруднениями & 16,8 & 17 & 16,7 & 24,8 & 9,7 \\
\hline Не знаю язык & 4,2 & 3,7 & 4,6 & 7,4 & 1,5 \\
\hline
\end{tabular}

\section{Сферы применения языков}

Важным аспектом в изучении поставленных выше вопросов, является изучение сфер применения языков респондентами. в связи с этим, были выделены три сферы: 1. Домашняя; 2. Рабочая и/или учебная; 3. Уличная. Этот вопрос особенно значим в связи с рассмотрением оценки адыгейского языка как уязвимого со стороны «Юнеско». 
В домашнем общении среди респондентов, как видно по таблице №4, преобладает адыгейский язык, который используется чуть менее чем $45 \%$ опрошенных. Второй по популярности ответ, это «русский и адыгейский языки» - 31\%. Исключительно русский язык дома использует $18 \%$ респондентов. Около $4 \%$ общаются на кабардино-черкесском.

Заметна разница в ответах мужчин и женщин: так, если почти половина мужчин (49\%) использует дома только адыгейский язык, то среди женщин доля таковых ниже почти на $8 \%$ и составляет $41 \%$. Русским и адыгейским языком совместно, чаще пользуются женщины - 35\% опрошенных, против $30 \%$ у мужчин. Исключительно русский язык использует 19\% мужчин и 17\% женщин соответственно. Кабардино-черкесский в домашнем общении чаще употребляется среди женщин, чем среди мужчин.

В то время, как около четверти горожан (24\%) используют дома исключительно адыгейский язык, среди респондентов, родившихся в селе, этот показатель выше почти в три раза - 70\%. Заметно, что ответ «русский и адыгейский» языки совместно встречается чаще среди ответов горожан - 42\%. Для села этот показатель оказался ниже практически вдвое - 23\%. Разница между городом и селом в отношении того, какое число респондентов использует исключительно русский язык в домашнем общении оказалась наибольшей. Если среди родившихся в сельской местности только 4,5\% используют дома исключительно русский язык, то для горожан этот показатель оказался выше более чем в шесть раз, составив 30\% от общего числа опрошенных в этой группе.

Таблица 4

На каких языках респонденты общаются дома (в \%)

\begin{tabular}{|c|c|c|c|c|c|}
\hline \multirow{2}{*}{ Вариант } & \multirow{2}{*}{ Общие } & \multicolumn{2}{|c|}{ Пол } & \multicolumn{2}{|c|}{ Место рождения } \\
\hline & & Мужчины & Женщины & Город & Село \\
\hline Адыгейский & 44,7 & 48,9 & 41,3 & 23,8 & 70,1 \\
\hline Кабардино-черкесский & 3,8 & 1,4 & 5,6 & 3,1 & 2,2 \\
\hline Русский & 17,8 & 19,1 & 16,8 & 30 & 4,5 \\
\hline Русский и адыгский & 32,8 & 29,8 & 35,2 & 41,9 & 23,1 \\
\hline
\end{tabular}

По оценкам респондентов, русский язык является для них главенствующим при общении на работе и/или учебе. Так, исключительно русский язык использует 2/3 респондентов (66\%), а совместно с адыгейским языком чуть менее третьей части (30\%). Чуть менее $2 \%$ респондентов для учебного и/или рабочего общения употребляют только адыгейский язык. Для кабардино-черкесского этот показатель оказался менее одного процента.

Как оказалось, мужчины и женщины в разных соотношениях используют выше обозначенные языки. Так, если русский и адыгейский языки среди обеих групп использует около трети респондентов, то исключительно русский язык для рабочего и/ или учебного общения чаще используют женщины $(68 \%)$, нежели мужчины $(64 \%)$. Чуть более половины процента $(0,6 \%)$ среди женщин предпочитают адыгейский язык, для мужчин этот показатель выше на три процента (3,5\%). Кабардино-черкесский же язык женщина на работе и/или учебе не используется вовсе, в то время как чуть более $2 \%$ мужчин находят ему применение в указанных сферах. 
Ожидаемые результаты показала разбивка по месту рождения. Для уроженцев города характерно преобладание в рабочем и/или учебном общении русского языка и наоборот, меньшая доля адыгейского. Так, среди указанной группы, более 70\% респондентов используют исключительно русский язык, в то время, как для сельчан этот показатель равен 55\%. Только адыгейский язык использует исключительно сельская молодежь - 4,5\%. Разница между городом и селом в отношении кабардино-черкесского языка составляет пол процента - чуть более $1 \%$ для горожан и менее $1 \%$ для сельчан. Заметно, что наиболее частое совместное применение русского и адыгейского языков встречается у сельской молодежи - $40 \%$ респондентов в указанной группе. Среди горожан, только четверть (25\%) использует подобную комбинацию языков на работе и/или учебе.

Таблица 5

На каких языках респонденты общаются на работе/учебе (в \%)

\begin{tabular}{l|c|c|c|c|c}
\hline \multirow{2}{*}{ Вариант } & \multirow{2}{*}{ Общие } & \multicolumn{2}{|c|}{ Пол } & \multicolumn{2}{c}{ Место рождения } \\
\cline { 3 - 6 } & & Мужчины & Женщины & Город & Село \\
\hline Адыгейский & 1,9 & 3,5 & 0,6 & 0 & 4,5 \\
\hline Кабардино-черкесский & 0,9 & 2,1 & 0 & 1,3 & 0,7 \\
\hline Русский & 65,9 & 63,8 & 67,6 & 73,1 & 55,2 \\
\hline Русский и адыгский & 30,3 & 29,8 & 30,7 & 25 & 38,1 \\
\hline
\end{tabular}

Около половины респондентов (51\%) при общении на улице используют русский язык. Чуть более трети опрошенных (35\%) в схожих условиях говорят на русском и адыгейском языках. Исключительно адыгейский или кабардино-черкесский язык употребляется гораздо реже: $8 \%$ и $2 \%$ соответственно.

На улице женщины чаще общаются на русском языке. Его предпочитают более половины опрошенных респонденток (57\%), в то время, как для респондентов мужского пола этот показатель составляет 44\%. Как и при общении на работе и/или учебе, мужчины чаще чем женщины используют адыгейский язык отдельно и в комбинации с русским языком. Около 40\% мужчин применяют русский и адыгейский языки вместе, против $32 \%$ женщин. Исключительно на адыгейском языке общаются на улице $12 \%$ мужчин. Для женщин, этот показатель составляет 5\%. Использование кабардино-черкесского языка также более свойственно мужчинам $(3,5 \%)$ нежели женщинам (1\%). в целом, заметна тенденция, что мужчины вне дома чаще общаются на адыгейском языке отдельно или совместно с русским. Возможно, этот факт связан с некоторой большей этнической и земляческой замкнутостью мужских коллективов. Следствием этого становится более этнически гомогенное окружение. Одна из возможных причин - стремление сохранить связь с аульскими друзьями (преимущественно адыгами), как одноклассниками, так и выпускниками старших классов той школы, в которой учились респонденты.

Городское или сельское окружение имеют определенное влияние на выбор респондентом языка общения на улице. Так неудивительно, что студенты, родившиеся в городе, где большая часть окружения являются русскими, чаще указывали исключитель- 
но русский язык - 63\%. Для респондентов, родившихся в сельской местности, доля тех, кто использует только русский язык при общении на улице составляет чуть более трети - 34\%. Сельчане, родившиеся в преимущественно адыгоязычном окружении, чаще городских жителей используют адыгейский язык отдельно или с русским языком вместе для общения на улице. Так $46 \%$ студентов, родившихся в сельской местности, указали русский и адыгейский языки, против $30 \%$ среди горожан. в уличном общении исключительно адыгейский язык использует $14 \%$ сельчан и $3 \%$ горожан соответственно. Около $2 \%$ в обеих группах общаются на улице на кабардино-черкесском языке.

Таблица 6

На каких языках респонденты общаются на улице (в \%)

\begin{tabular}{|c|c|c|c|c|c|}
\hline \multirow{2}{*}{ Вариант } & \multirow{2}{*}{ Общие } & \multicolumn{2}{|c|}{ Пол } & \multicolumn{2}{|c|}{ Место рождения } \\
\hline & & Мужчины & Женщины & Город & Село \\
\hline Адыгейский & 8,1 & 12,1 & 5 & 3,1 & 14,2 \\
\hline Кабардино-черкесский & 2,2 & 3,5 & 1,1 & 1,9 & 2,2 \\
\hline Русский & 51,3 & 44 & 57 & 63,1 & 34,3 \\
\hline Русский и адыгский & 35,6 & 39,7 & 32,4 & 29,4 & 46,3 \\
\hline
\end{tabular}

Студентам, принимавшим участие в опросе, было предложено ответить на вопрос «Если Вы не общаетесь с окружающими на родном языке, то по какой причине?». Результаты и предлагавшиеся варианты указаны в таблице №7. Заметим, что в этом вопросе респонденты могли выбрать одновременно несколько вариантов ответа. Более половины опрошенных (52\%) указали, что они не общаются на родном языке изза того, что окружение не знает этот язык. У $37 \%$ респондентов, по их собственным словам, не возникает проблем при общении с окружающими людьми. Отметили, что не знают или мало знают родной язык $13 \%$, еще около $10 \%$ испытывают стеснение при его использовании, 4\% дали другой ответ.

Определенный интерес составляет разбивка ответов на этот вопрос по полу. Так, примерно по 10\% в обеих группах испытывают стеснение при использовании родного языка. Не знают или мало знают родной язык 14\% мужчин, против $12 \%$ у женщин. Другой ответ указали 5\% и 3\% соответственно. Около 43\% мужчин заявили об отсутствии проблем при общении с окружающими на родном языке. Среди женщин, этот показатель оказался ниже на 10\%, составив 32\%. Примечательно, мужчины реже заявляли, что окружающие не знают родной язык респондента - 44\%, против 58\% у женщин. Эти данные, а конкретно, большее число респондентов мужчин (по отношению к женщинам) не испытывающих проблем при общении с окружающими на родном языке, могут указывать на ранее озвученное предположение о большей этнической гомогенности мужского коллектива у адыгов. Так же, в пользу этого может говорить тот факт, что женщины чаще сталкиваются с ситуацией, когда окружающие не знают адыгейский язык. Следовательно, они обычно находятся в более полиэтничной среде.

Среди прочих вариантов ответа, несколькими респондентами было указано, что им удобнее общаться на русском языке, или что еще с детства они общались только на нем. Также был встречен ответ «Вы тоже не общаетесь». Видимо, имелось в виду, что мое общение с респондентами проходило на русском языке. 
Таблица 7

\section{По какой причине(ам) респонденты не общаются с окружающими на родном языке (в \%)}

\begin{tabular}{l|c|c|c|c|c}
\hline \multirow{2}{*}{ Вариант } & \multirow{2}{*}{ Общие } & \multicolumn{2}{|c|}{ Пол } & \multicolumn{2}{|c}{ Место рождения } \\
\cline { 3 - 6 } & & Мужчины & Женщины & Город & Село \\
\hline $\begin{array}{l}\text { Не знаю родной язык } \\
\text { (мало знаю) }\end{array}$ & 13,1 & 14,2 & 12,3 & 23,8 & 1,5 \\
\hdashline $\begin{array}{l}\text { Окружающие не знают } \\
\text { моего языка }\end{array}$ & 51,6 & 44 & 57,5 & 41,9 & 62,7 \\
\hdashline $\begin{array}{l}\text { Испытываю стеснение } \\
\text { при использовании родного языка }\end{array}$ & 10 & 9,9 & 10,1 & 15 & 1,5 \\
\hdashline $\begin{array}{l}\text { У меня нет проблем, я общаюсь с } \\
\text { окружающими на родном языке }\end{array}$ & 36,6 & 42,6 & 31,8 & 30 & 44,8 \\
\hline \begin{tabular}{l} 
Другой ответ \\
\hline
\end{tabular} & 3,8 & 5 & 2,8 & 5 & 1,5 \\
\hline
\end{tabular}

Также стоит сказать о достаточно больной теме соотношения адыгского, адыгейского и черкесского языков. Название «адыги» является обобщающим понятием для адыгских народов, в список которых входят адыгейцы, кабардинцы, черкесы, шапсуги, бжедуги, темиргоевцы и прочие. Из-за этого зачастую среди адыгской общественности звучит критика по отношению к тем, кто использует названия «адыгеец», «черкес», «шапсуг», «кабардинец», т.к. считается, что это «разъединяет народ». Тем не менее, в последние годы и особенно в преддверии предстоящей Всероссийской переписи населения, часть адыгских активистов начала деятельность по пропаганде «черкесскости» и призывам, чтобы адыги записывали себя как «черкесы» в переписных листах. Волна интернет публикаций и флешмобов прокатилась по русскоязычному интернету в 2020 году и в некоторой степени затронула 2021 год. Типичны такие комментарии: «Опять черкесский язык (адыгэбзэ) делят на «адыгейский» (чемгуйский диалект из кяхской диалектной группы) и «кабардино-черкесский» (бесленее-кабардинский диалект). Когда же эту ересь прекратят? А так все понятно: в ТРЕХ субъектах федерации черкесский язык имеет «государственный статус» и НИ в ОДНОМ он не используется в делопроизводстве, а также НИ в ОДНОМ нельзя получить даже среднего образования на нем, не то что высшего - про переводы классической и актуальной литературы, а также дубляж фильмов, софта, игрушек и пр. вообще молчу. Языки полностью выдавлены в бытовую сферу, имеют неудобную алфавитную базу, которую даже люди для которых он родной и практически единственный толком использовать не могут - спотыкаются. ЭТО РЕАЛЬНОСТЬ. И НИЧЕГО для того, чтобы переломить ситуацию не делается, увы...» (Кавказский узел: 1). Как ни странно, респонденты, являющиеся активными пользователями социальных сетей и по всей видимости, знакомые с агитационной компанией «черкесских» активистов, не проявляли возмущения на приведенные в опроснике формулировки по типу «адыгейский язык». Лишь некоторое количество респондентов указывало «адыгский», «кабардинский» и «черкесский» языки в категории «другое».

Рассуждая о причинах подобного положения дел, можно выделить несколько основных моментов, из-за которых адыгейский язык вытесняется из различных сфер 
жизни: 1. Экономическая; 2. Статусная; 3. Образовательная; 4. Миграции внутри Республики и связанные с этим процессы.

Касаемо экономического аспекта отметим, что авторы работы «Употребление иноязычных заимствований в современных адыгейских СМИ» Читао Л.Р, и Алентьева М.А. произвели анализ «50 номеров газеты «Адыгэ макъ» за 2013-2014 гг.» и пришли к следующему выводу: «Иноязычные заимствования, прежде всего, затрагивают сферу экономической жизни, потому что именно здесь возникает самая острая потребность в обозначении многих новых для нас понятий и реалий, связанных с рыночной экономикой и давно имеющих свою номинацию на Западе... Значительно расширяется сфера употребления таких слов, как инвестиция, инвестор, менеджер, фирма и др. Сегодня они встречаются не только в профессиональной речи финансистов и экономистов, но и в разговорно-бытовой сфере. Особенно часто встречается слово фирма» (Читао, Алентьева 2015: 126-127).

Бабич И.Л., исследовавшая жизнь современных причерноморских шапсугов замечает, что «снижение интереса как к литературному адыгейскому, так и шапсугскому языкам было связано с новыми социально-экономическими и культурными факторами», такими как: участившиеся межэтнические браки, в таких семьях в домашнем общении преимущественно используется русский язык; языковое противоречие, являющееся следствием домашнего общения на шапсугском диалекте, в то время как преподавание в школе проходит на адыгейском литературном; «невозможность применения знания адыгейского языка в экономической и социальной жизни, где стал преобладать русский язык» (Бабич 2019: 140-141). Так, имевшиеся рабочие места в местных совхозах, чайных плантациях и прочих производствах позволяли сотрудникам шапсугам общаться на шапсугском языке. Но после их разрушения, пришедшая туристическая отрасль привела к оттоку трудоспособного населения на побережье, где основным языком общения является русский: «Таким образом, изменения в экономике вытеснили шапсугский язык из экономической сферы жизни причерноморских шапсугов» (Бабич 2019: 151).

Можно вспомнить одно из выступлений на XIX отчетно-выборном съезде Адыгэ Хасэ, состоявшемся в январе 2017 года, в котором отмечалось, что решение вопроса сохранения адыгейского языка и культуры связано с экономическими и трудовыми проблемами. Необходимость работать с раннего утра и до поздней ночи обоим супругам, приводит к тому, что ребенок остается целиком и полностью в русскоязычном окружении без родителей, которые могли бы общаться с ним на адыгейском языке и прививать традиции народа. Можно заметить, что подобная ситуация особенно актуальна для городских семей и несколько меньше для сельских. Так, в условиях городской застройки трехпоколенные семьи встречаются крайне редко, как следствие, семьи в основном состоят из родителей и детей. Если в сельской местности вопросы воспитания и приобщения к языку решались за счет присутствия бабушек и дедушек, то в городе это становится сложнее, особенно, если учитывать, что нередко среднее поколение переезжает в город, в то время, как старшее поколение продолжает жить в сельской местности: «Проблеме не один год. Корнями она уходит в стремительную урбанизацию конца 80-90-х годов прошлого века, когда переехавшие в Майкоп или Краснодар аульчане переставали говорить на родном языке. Причём, даже между собой. А многие черкесские дети, родившиеся и выросшие в городской среде, вообще не знают адыгейского» (A-Хэку). 
Определенное значение имеет постепенный отток адыгов не только в город, но также в села и хутора с преимущественно русским населением. Так, если в 1989 году, соотношение городской и сельской части адыгов в Адыгее составляла 1 к 2, то в 2010 году оно примерно сравнялось (Донежук 2020: 219). Похожая тенденция наблюдается и среди шапсугов: «Безусловно, в аулах с преобладающим шапсугским населением бытование шапсугского языка значительно шире, чем в смешанных поселках. Однако количество смешанных по составу населенных пунктов в Причерноморье неуклонно увеличивается, а сфера применения шапсугского языка сокращается» (Бабич 2020: 153). Тем самым получается формирование полиэтничной среды, где использование адыгейского языка, которым большая часть не владеет, становится затрудненным и сильно ограниченным. Как было показано выше, даже в домашнем общении адыги, родившиеся в городе, реже используют адыгейский язык, нежели те, кто родился в сельской местности. Можно предположить, что и полиэтничная сельская среда сходным образом будет влиять на владение и применение адыгейского языка. Урбанизация и постепенно увеличивающаяся этническая гетерогенность аулов влияют даже на преподавание адыгейского языка и литературы: «Если в классе обучаются дети адыгской национальности вместе с русскоязычными, опрошенные преподаватели считают целесообразным дублировать условия заданий и правила на русском языке. Трое преподавателей средних и старших классов аульской школы отметили, что, хотя занятия ведутся на адыгейском языке, они повторяют инструкции к заданиям на русском языке, чтобы все учащиеся понимали, что от них требуется в данный момент» (Минакова, Унарокова 2020: 78). Причем, автор этой статьи может заметить, будучи выпускником полиэтничной школы, что преподавание адыгейского языка и литературы всегда имело свои определенные нюансы, заключающиеся не только в дублировании заданий, но также в методологических и даже физических сложностях. Так, учителю бывало сложно раскрыть тему целиком или проверить знания всех учеников за одно 45-минутное занятие из-за того, что само повторение одного и того же материала дважды отнимает много времени. Помимо этого, сказывается ограниченность в выделенных для преподавания адыгейского языка и литературы часах, также не позволяющих нивелировать специфику преподавания в этнически гетерогенном классе.

Вопрос образования оказывается еще более сложным, т.к. к полиэтнической составляющей добавляется определенная языковая гетерогенность адыгов, а также различия в уровне владения адыгейским языком у обучающихся. Так, в Адыгее проживает некоторое количество кабардинцев, расселенных преимущественно в отдельных аулах: Кошехабль, Ходзь и Блечепсин. Во время Кавказской войны они переселились из Кабарды на территорию нынешнего Кошехабльского района. За прошедшее время, несмотря на введение и преподавание литературной нормы адыгейского языка, основанной на темиргоевском диалекте, отличном от кабардинского, население этих аулов не утратило свой кабардинский язык. Заметим, что кабардинский заметно отличается как от литературной нормы, так и от бжедугского, темиргоевского, шапсугского, абадзехского диалектов. Этот факт приводит к определенным последствиям: «адыгейский литературный язык сложно дается некоторым детям кабардинцам», в связи с этим некоторые ученики используют на уроках кабардинский язык. Так, «ученик крайне расстроился, когда был исправлен его ответ на кабардинском» (Минакова, Унарокова 2020: 79). Впрочем, не всегда употребление кабардинского языка встречается «в штыки»: «По замечанию некоторых участников, на уроках которых доминирует адыгей- 
ский язык, они могут перейти на русский, если замечают, что ученики не понимают тему. Один из преподавателей средних классов аульской школы отметила, что в таких случаях может использовать русский или кабардинский, который является родным для учеников в ее классе» (Минакова, Унарокова 2020: 78).

К ранее озвученным проблемам можно добавить и разный уровень владения адыгейским языком учениками школ: «По словам преподавателей, в одном классе могут обучаться дети хорошо говорящие на адыгейском, те, кто понимает его на слух, но не говорит, и те, кто пока владеет им слабо или не владеет вообще» (Минакова, Унарокова 2020: 78). Как отмечала Хамерзокова Н.А., подобная ситуация наблюдается и в сфере высшего образования, в частности на факультете адыгейской филологии и культуры: «Сейчас слабые абитуриенты в плане владения адыгейским языком и вообще всего. Когда мы работаем с теми, кто приходит на факультет, некоторые хорошо знают язык, некоторые хуже. Уровень и техника чтения разная. Они не читают не только по-адыгейски, но и по-русски. Плохая база, недостаточное знание языка, более примитивная молодежная лексика при прохождении учебного процесса на факультете, сталкиваются с хорошими текстами, научной литературой на адыгейском языке и программой, ориентированной на лучшее знание языка». Эта особенность, а также невозможность индивидуального подхода к обучающимся, основанном на индивидуальном уровне владения языком, приводит к усреднению требований по отношению к ученикам, а также студентам. Рассуждая о причинах этого, Хамерзокова Н.А. заметила: «Знания сильно ослабли. Особенно обострилась эта ситуация после введения ЕГЭ. Произошел сильный отток из школ после 9 класса. Колледжи забирают их, а в колледжах адыгейского языка нет. Т.е. они теряют базу 10-11 класса, на которой мы работаем со студентами. Те, кто оканчивают 10-11 классы, адресно нацеливаются на хорошие столичные вузы».

Как пишет авторы статьи «Языки меньшинств и устойчивый перевод: угроза или возможность?», социально-экономические и социально-политические факторы оказывают большое влияние на развитие языков меньшинств. в частности, на примере баскского языка показывается, что языки, ассоциирующиеся со «стыдом и отсталостью», называемые зачастую «сельскими», после политической поддержки, приобретения более престижного статуса, получают большее распространение и популярность. Помимо этого, баскский язык начинает восприниматься многими как важный язык на рынке труда (Cenoz, Gorter 2017: 3). Тем не менее, авторы признают, что баскский как и многие другие языки меньшинств находятся под влиянием более крупных языков. При этом, большую роль играет определенная изолированность языков для различных, некогда новых сфер жизни в прошлом, а также фактическое существование языка только в образовательной системе (Cenoz, Gorter 2017: 4). Что касается адыгейского языка, то к нему во многом продолжает сохраняться несколько пренебрежительное отношение. Так, на одном из факультетов автору довелось пообщаться с членом преподавательского коллектива, который говорил о скорой гибели языка, его ненадобности и неприменимости в трудовой сфере. Вообще, в обществе продолжает сохраняться тезис, что «за Кубанью адыгейский язык не нужен» и языком престижа является русский. Также, со слов одного из преподавателей, у некоторых студентов адыгов имеется страх «показаться дикарями». Это проявляется в опаске признания адыгской, родной для этих студентов культуры и языка как низкой или даже второсортной. «Наши студенты, адыги, очень закомплексованные», - 
отметил преподаватель. К этому можно добавить стыд некоторой части молодежи за «ненадлежащее» знание и владение адыгейским языком. Так, декан Факультета адыгейской филологии и культуры Н.А. Хамерзокова заметила: «В обществе надо переломить, что человека стыдят из-за его незнания родного языка или из-за неправильно сказанного слова. Молодежь часто стесняется, хочет сказать, понимает, но психологический барьер мешает. Боятся быть высмеянными. Нельзя порицать и говорить: «Стыдно не знать родной язык». Наоборот надо поощрять, пускай говорят пусть и неправильно, это же не экзамен. Надо поддерживать мотивацию говорить».

К вопросу статусности адыгейского языка можно добавить продолжительное время навязывавшиеся представления о неэтичности использования адыгейского языка в присутствии людей, которые его не знают. Так, сразу несколько преподавателей вузов, с которыми автору статьи довелось пообщаться, отмечали, что в детские годы, когда они жили и учились в Майкопе, им прививалась идея, что в полиэтничном окружении неприлично разговаривать на адыгейском языке, даже если общение ведется с другим адыгом. в условиях, когда в Майкопе и соответственно в абсолютном большинстве школ адыгов было мало, а окружение не знало адыгейский язык, это приводило к крайне редкому его использованию. Один из преподавателей отметил, что в связи с этим у него развилось некоторое чувство стыда, для преодоления которого потребовалось много времени. Судя по личным наблюдениям автора, подобная ситуация продолжает сохраняться пусть и в менышем масштабе. Во время работы в детском лагере, автор являлся свидетелем разнообразных споров в отношении применимости адыгейского языка. Так, среди вожатых периодически возникало возмущение, когда некоторые из них общались друг с другом на адыгейском языке в присутствии тех, кто им не владеет. в подобных случаях, часто звучали слова: «Общайтесь на том языке, который все понимают». Некоторые вожатые использовали такие слова в отношении детей. Помимо этого, подобное возмущение периодически наблюдалось и среди самих детей. Как показывает опыт общения с вожатыми и детьми, большей частью требования «говорить на понятном всем языке» возникают из опасений заговорщичества, обсуждения тех, кто не понимает адыгейский язык.

T.e. можно сказать, что адыгейский язык находится в противоречивом состоянии: сам язык не воспринимается престижным и востребованным, связан с культурой, которая на фоне соседствующей постоянно находится под угрозой признания как «низкой», при этом частью общества порицается незнание языка. Молодые люди оказываются в ситуации, когда непонятно к какому берегу можно было бы прибиться. Помимо этого, сам регион, т.е. Республика Адыгея, а также сферы возможного применения языка в экономическом отношении продолжают оставаться весьма ограниченными.

Отток молодежи в соседний регион, переход молодых специалистов из сферы образования и науки в коммерческую среду имеют материальную подоплеку. Причем, подобная тенденция распространяется не только на тех, для кого адыгейский язык является или мог бы являться инструментом для заработка, но также и на представителей естественно-научных дисциплин и специальностей. Так, проводя опрос в одном из высших учебных заведений Майкопа, автор стал свидетелем разговора одного из преподавателей с молодым специалистом. Преподаватель отчитывал последнего из-за нежелания молодого человека защищать кандидатскую степень в своей области. Также, старший по возрасту и статусу специалист заметил, что на их ка- 
федре и направлении в Адыгее «уже нет адыгов», т.е. замены для ныне действующих национальных кадров практически нет. На это молодой специалист сослался на отсутствие перспективы и адекватной зарплаты в научной и образовательной отрасли, которая позволила бы спокойно жить. Он также заметил, что готов уйти, как только найдется хорошо оплачиваемая работа пусть и в другом месте.

Помимо этого, при рассмотрении возможных причин подобного положения, появилось предположение, что дети из полиэтничных семей могут реже или даже несколько хуже знать адыгейский язык. К такому предположению подтолкнули частые комментарии самих респондентов, которые указывали, что дети различных по национальности родителей хуже знают адыгейский язык.

Среди опрошенных студентов, доля детей из полиэтничных семей составила $11 \%$. И несмотря на тот факт, что эта группа является слишком малочисленной для полноценного сравнения с результатами, полученными от респондентов из моноэтничных семей, тем не менее, весомые отличия в ответах позволяют достаточно осторожно судить о влиянии этого фактора на языковое поведение и языковые компетенции. Так, в ответах на вопрос: «Какими языками Вы владеете?», 91\% респондентов из моноэтничных семей отметили, что владеют адыгейским языком. Доля таковых из полиэтничных семей оказалась более чем в два раза ниже, составив 40\%. Оценивая свое знание адыгейского языка, 67\% детей из исключительно адыгских семей отметили, что думают на этом языке, свободно говорят, читают и пишут. Может читать и говорить, но думает на другом языке $17 \%$, еще $12 \%$ говорит на адыгейском языке с затруднениями. Вовсе не знает язык 4\% респондентов в этой группе. Только 17\% опрошенных студентов из полиэтничных семей думают на адыгейском языке, чуть менее $6 \%$ может говорить, читать и писать на указанном языке, но думает на отличном от него. Более половины, 51\% говорит на адыгейском языке с затруднениями и еще $14 \%$ вовсе им не владеет.

Полученные выше результаты становятся еще более отчетливыми при соотнесении их с вопросом: «На каких языках Вы говорите с окружающими дома, на работе/учебе, на улице?». Так, для домашнего общения респонденты из моноэтничных семей чаще используют адыгейский язык отдельно и/или совместно с русским: только адыгейский $-50 \%$, русский и адыгейский - $34 \%$. Лишь $11 \%$ респондентов в указанной группе говорит дома исключительно на русском языке. Еще чуть более 4\% общаются на кабардино-черкесском. При этом домашнее общение на адыгейском языке в полиэтничных семьях встречается практически в пять раз реже, чем в моноэтничных - $11 \%$ против 50\% соответственно. Заметно преобладание русского языка: $70 \%$ респондентов из семей с родителями разных национальностей указали этот язык, 20\% опрошенных в данной группе общаются дома на русском и адыгейском языках. Стоит отметить, что этническая гомогенность или гетерогенность родителей влияет на выбор языка для общения на работе, учебе и улице. Так, $2 \%$ детей из моноэтничных семей для общения на учебе и/или работе применяют адыгейский язык, 1\% кабардино-черкесский, треть - 33\% русский и адыгейский и $63 \%$ исключительно русский язык. Во второй группе респондентов никто не отметил вариант с кабардино-черкесским, 3\% указали адыгейский язык, $11 \%$ русский и адыгейский и $83 \%$ указали исключительно русский язык как язык для учебного и/или рабочего общения. Для 9\% выходцев из этнически гомогенных семей общение на улице, происходит на адыгейском языке, для 2,5\% на кабардино-черкесском. Из этой группы $39 \%$ респондентов предпочитают русский 
и адыгейский языки вместе и 46\% исключительно русский. Опрошенные студенты, родившиеся в семьях с отличными по национальности родителями, в подавляющем большинстве (86\%) общаются на улице исключительно на русском языке, $11 \%$ указали русский и адыгейский, только $3 \%$ адыгейский. И ни один не отметил кабардино-черкесский язык как язык уличного общения.

Любопытны результаты сравнения ответов на вопрос «Если Вы не общаетесь на родном языке, то по какой причине?» в указанных группах. Из моноэтничных семей $10 \%$ респондентов против $37 \%$ из полиэтничных не знают или слабо знают адыгейский язык. 57\% опрошенных в первой группе отмечали, что окружающие не знают их язык. Среди выходцев из этнически гетерогенных семей, подобный вариант выбрало 17\% респондентов. Испытывают стеснение при использовании родного языка примерно равные доли в обеих группах: $10 \%$ и 9\% соответственно. При этом $36 \%$ детей из моноэтничных и $40 \%$ из полиэтничных семей заявили, что не имеют проблем при общении с окружающими на родном языке.

Тем самым, можно заметить, что между группой респондентов из этнически гомогенных и группой этнически гетерогенных семей имеется весьма существенная разница в отношении владения и применения адыгейского языка. Так, в семьях где оба родителя являются адыгами, в целом респонденты лучше знают язык, а также чаще применяют его в общении как дома, так и в различных сферах жизни. Оговоримся, что в первой группе студентов примерно равное соотношение выходцев из города и села: $47 \%$ и 44\% соответственно. Респонденты же из полиэтничных семей чаще оказывались именно городскими - 69\% против 26\%. Этот факт, скорее всего также влияет как на уровень знания, так и на сферы применения. Если в сельской местности, преимущественно аульской, есть достаточное окружение для общения на адыгейском языке, то в городе, где доля адыгов крайне незначительна, подобных возможностей мало.

Полученные результаты позволяют хотя и с некоторой осторожностью согласиться, что оценка данная адыгейскому языку ЮНЕСКО, как «уязвимому», исходя из объяснения этого термина в «Атласе языков народов мира находящихся под угрозой исчезновения» («уязвимый язык - большинство детей говорит на этом языке, но он может быть ограничен определенными областями /например, домом/») (Атлас языков) является справедливой. Адыгейский язык в значительной мере используется в домашнем общении, преимущественно среди сельских жителей. Большой комплекс проблем: статусных, социальных и экономических являются труднопреодолимыми. Тем не менее, адыгская общественность продолжает свою борьбу за сохранение языка. Общественная организация «Адыгэ-Хасэ» ведет мониторинг оснащенности аульских школ литературой на адыгейском языке. Адыгейский государственный университет формирует программу по сохранению адыгейского языка, а его структурное подразделение - Факультет адыгейской филологии и культуры занимается разработкой новых программ обучения. Также, сотрудниками ВШЭ был создан корпус адыгейского языка, позволяющий работать с адыгейским языком как филологам, лингвистам, так и тем, кому он интересен.

К сожалению, несмотря на вышеназванные подвижки, экономический вопрос, а конкретнее узость рынка труда, где востребован или применим адыгейский язык и вытекающие из этого последствия, в виде малого престижа языка, слабого употребления еще не решены. 


\section{Источники и материалы}

Атлас языков - Атлас языков народов мира находящихся под угрозой исчезновения. http://www. unesco.org/languages-atlas/index.php?hl=en\&page=atlasmap (дата обращения: 06.07.21)

А-Хэку - А-Хэку. в Адыгее родной язык пытаются сохранить с помощью гаджетов и мультфильмов. https://aheku.net/news/society/v-adyigee-rodnoj-yazyik-pyitayutsya-soxranit-s-pomoshhyu-gadzhetov-i-multfilmov (дата обращения: 11.07.21).

Денисова 2018 - Денисова А.В. Языковые предпочтения молодежи республик ЮФО: сравнительный анализ ситуации в Республике Крым, Адыгеи, Калмыкии // Ученые записки Крымского федерального университета им. В.И. Вернадского. Социология. Педагогика. Психология, 2018. № 1S. С. 153-158.

Женщины и мужчины 2020 - Женщины и мужчины России. 2020: Стат. сб. М.: Росстат, 2020. C. 239.

Кавказский узел - Кавказский узел. ЮНЕСКО признала языки народов Северного Кавказа исчезающими. https://www.kavkaz-uzel.eu/articles/150042/ (дата обращения: 11.07.21).

Мы должны - Мы должны сохранить в себе все адыгское. https://ok.ru/adigagroup/topic/63790238897422 (Дата обращения: 11.07.2021).

Нехай 2008 - Нехай В.Н. Межнациональное общение как фундаментальное условие интернационализации духовной жизни в полиэтничном регионе // Вестник Адыгейского государственного университета. Серия 1: Регионоведение: философия, история, социология, юриспруденция, политология, культурология, 2008. № 2. С. 102-105.

Унарокова 2017 - Унарокова Р.Б., Бижева 3.Х., Цеева 3.А., Унарокова Ф.Д. Лексикографическая база данных адыгских языков: основные принципы построения // Вестник Адыгейского государственного университета. Серия 2: Филология и искусствоведение, 2017. № 4 (207). С. 126-132.

Цветков 2018 - Цветков О. М. Адыгейский язык: поиск путей сохранения и развития // Гуманитарные и социально-политические проблемы модернизации Кавказа: Материалы VI-ой Международной конференции, Магас, 10-13 мая 2018 года / ФГБОУ ВО «Ингушский государственный университет». Магас: ООО «КЕП», 2018. С. 489-495.

Черкесскому языку - Черкесскому языку грозит исчезновение - Caucasus Times. http:// circassiatimesrussian.blogspot.com/2016/12/caucasus-times.html (дата обращения: 11.07.21).

\section{Научная литература}

Бабич И.Л. Современные языковые процессы как фактор национальной идентичности причерноморских адыгов-шапсугов // Смерть языка - смерть народа? Языковые ситуации и языковые права в России и сопредельных государствах. М.: ИЭА РАН им. Н.Н. Миклухо-Маклая РАН, 2020. 260 с.

Донежук М.Ю. Уважение старших у адыгов: возникновение и трансформация традиции // Вестник антропологии, 2020. № 4 (52). С. 210-223.

Минакова В.Ю., Унарокова Р.Б. Принципы «трансъязычия» и преподавание миноритарных языков на примере адыгейского языка: к постановке проблемы // Вестник Адыгейского государственного университета. Серия 2: Филология и искусствоведение, 2020. № 4 (267). C. $74-81$.

Читао Л.Р., Алентьева М.А. Употребление иноязычных заимствований в современных адыгейских СМИ // Вестник Адыгейского государственного университета. Серия 2: Филология и искусствоведение, 2015. № 2 (153). С. 124-128.

Cenoz J., Gorter D. Minority languages and sustainable translanguaging: threat or opportunity? // Journal of Multilingual and Multicultural Development. Informa UK Limited, 2017. Vol. 38 (10). P. 901-912. 
Donezhuk, Murat Yu.

\section{Linguistic Behavior and Competencies of the Adyghe Students}

DOI: $10.33876 / 2311-0546 / 2021-4 / 75-91$

The linguistic competencies of the Adyghe students and, more specifically, the Adyghe language proficiency and its use have been a concern of the Adyghe community for a long time. The media and the Internet occasionally discuss the danger of "losing the Adyghe language" within young people and its "close death." Based on the results of a mass survey conducted in the city of Maykop, the author examines the language competencies of the student youth of the Republic of Adygea and how they use different languages in different spheres. The study revealed that the Russian language prevails in street communication, in class, and at work. The Adyghe language is mostly spoken at home. At the same time, it is shown that urban youth, in contrast to the rural one, less often uses the Adyghe language, giving preference to Russian. Almost all respondents have an excellent command of Russian, i.e., they think, read and write in it, while the share of Adyghe students who equally estimated their command of Adyghe is less than 2/3. Based on literature review and interview materials, the author explains the processes of displacement of the Adyghe language into the home environment and the reasons for the significant imbalance in the language proficiency and use between the urban-born and village-born respondents. These reasons include economic changes, active urbanization and internal migration, a more multiethnic environment in villages, problems in schooling and higher education.

Keywords: linguistic behavior, Adyghe language, Adyghe, Adygea, language use

For Citation: Donezhuk, M.Yu. 2021. Linguistic Behavior and Competencies of the Adyghe Students. Herald of Anthropology (Vestnik Antropologii) 4: 75-91.

Author Info: Donezhuk, Murat Yu. - PhD student, Institute of Ethnology and Anthropology RAS (Moscow, Russia). E-mail: donmur@iea.ras.ru

Funding: The study was carried out with the financial support of the Russian Foundation for Basic Research, scientific project No. 19-09-00482 A.

\section{References}

Babich I.L. 2020. Sovremennye jazykovye processy kak faktor nacional'noj identichnosti prichernomorskih adygov-shapsugov [Modern linguistic processes as a factor in the national identity of the Black Sea Circassians-Shapsugs]. In Smert'jazyka - smert'naroda? Jazykovye situacii i jazykovye prava v Rossii $i$ sopredel'nyh gosudarstvah [Is the death of the language the death of the ethnic group? Language situations and language rights in Russia and neighboring countries], edited by S.V. Sokolovsky, E.I. Filippova, 210-223. Moscow: N.N. Mikluho-Maklay Institute of ethnology and anthropology RAN.

Chitao L.R., Alent'eva M.A. 2015. Upotreblenie inojazychnyh zaimstvovanij v sovremennyh adygejskih SMI [The use of foreign-language borrowings in the Adyghe modern mass media]. Vestnik Adygejskogo gosudarstvennogo universiteta 153: 124-128.

Donezhuk M. Ju. 2020. Uvazhenie starshih u adygov: vozniknovenie i transformacija tradicii [Respect for the elders among the Adygs: the emergence and transformation of the tradition]. Vestnik antropologii 52: 210-223.

Minakova V.Ju., Unarokova R.B. 2020. Principy «transjazychija» i prepodavanie minoritarnyh jazykov na primere adygejskogo jazyka: k postanovke problemy [Principles of "translanguaging" and minority language teaching using an example of the Adyghe language: problem statement]. Vestnik Adygejskogo gosudarstvennogo universiteta 267: 74-81. 